\title{
El viaje en Palmerin de Olivia: sentido y estructura
}

\author{
M. a del Pilar Casado Gutiérrez \\ Universidad de Jaén
}

Título: El viaje en Palmerín de Olivia: sentido y estructura.

Resumen: El presente artículo estudia la estructura de los episodios relativos a los viajes del protagonista de Palmerín de Olivia, publicado en 1511, y cómo la disposición narrativa de estos relatos se relaciona con la configuración de los personajes. De esta manera se demuestra que la narración de los dos viajes marítimos que realiza el caballero está claramente imbricada en su construcción como personaje.

Palabras clave: Palmerín de Olivia, Viaje, Entrelazamiento, Estructura, Subordinación.

Fecha de recepción: 9/6/2020.

Fecha de aceptación: 30/7/2020.
Title: The Journey in Palmerin de Olivia: Meaning and Structure.

Abstract: This article studies the structure of the episodes related to the trips of the protagonist of Palmerin de Olivia, published in 1511, and how the narrative disposition of these stories is related to the configuration of the characters. In this way, it is shown that the narration of the two maritime voyages carried out by the knight is clearly interwoven in his construction as a character.

Key words: Palmerín de Olivia, Trip, Entanglement, Structure, Subordination.

Date of Receipt: 9/6/2020.

Date of Approval: 30/7/2020.

\section{INTRODUCCIÓN}

En algunos estudios sobre el género caballeresco aún se sigue considerando que los libros de caballerías presentan una estructura apoyada en la acumulación de episodios — o episodios en sarta — según la cual se origina una historia ilimitada donde las aventuras se suceden unas tras otras repitiéndose modelos y esquemas como meros clichés. Argumenta Rey Hazas que esto "posibilita y explica los ciclos prolongados de Amadises y Palmerines, en interminable sucesión de descendencia caballeresca, nove- 
la tras novela"1. Según el citado investigador, este tipo de estructura viene determinado por Amadis de Gaula (1508), obra paradigmática del género que asentó las características fundamentales de los libros de caballerías posteriores $^{2}$. Sin embargo, sería erróneo definir más de setenta títulos que aparecen en el panorama literario de los siglos XVI y XVII con los rasgos principales del texto amadisiano, el cual — no lo olvidemos- es una reescritura de un texto del siglo $\mathrm{XIV}^{3}$. De hecho, no tardarán en aparecer otras obras que, teniendo muy presente el Amadis como referente más inmediato, muestran marcadas diferencias también en lo que se refiere a la disposición narrativa ${ }^{4}$.

No obstante, debemos tener en cuenta una serie de motivos editoriales: el hecho de que presenten ciertas características y similitudes con otras obras hará posible su identificación y pertenencia a un género. Esto resulta más evidente en cuestiones de formato (portada, tamaño, distribución del texto, etc.), convenciones que servían para que el lector - y posible comprador - pudiera identificar el género al que pertenecían ${ }^{5}$. Asimismo, la noción de "género" que se estaba formando en ese momento también determinaba la composición narrativa, lo que no suponía un obstáculo para que cada obra ofreciera ciertas peculiaridades.

El propósito de este trabajo será analizar la estructura de determinados episodios de Palmerín de Olivia, en concreto aquellos del viaje que realizará el héroe a tierras infieles. Se demostrará que tramas y subtramas se van subordinando para configurar un armazón complejo en el que cada aventura va complicando y trasformando la personalidad del héroe.

1 Antonio Rey Hazas, "Introducción a la novela del Siglo de Oro, I. (Formas de la narrativa idealista)", Edad de Oro, 1 (1982), pp. 65-105 (p. 76).

2 Aunque el investigador se refiera a estos dos ciclos en concreto, su mención abarcaría a todas las series caballerescas.

3 Por otra parte, algunas de las características del texto de Montalvo son distintas a las propuestas por parte de la crítica, como su estructura, de tipo más hipotáctico de que se ha querido ver.

4 Para esta cuestión, vid. José Julio Martín Romero, "Palmerín de Olivia como enmienda del modelo amadisiano: el rechazo de la perfección arquetípica”, Revista de Literatura, LXXVI, 152 (2014) pp. 425-445.

5 Para conocer cualquier dato sobre los libros de caballerías y la imprenta, vid. José Manuel Lucía Megías, Imprenta y libros de caballerias, Madrid, Ollero \& Ramos, 2000. 


\title{
2. La estructura del PaLmeríN
}

El libro del famoso e muy esforçado cavallero Palmerín de Olivia se imprime en las prensas salmantinas de Juan de Porras en 1511. En esta obra, la narración biográfica del caballero sirve como eje vertebrador en torno al cual se articulan el resto de tramas y personajes. Sobre los temas que conforman las historias caballerescas, en concreto acerca del Amadis, Cacho Blecua señala que existen:

\begin{abstract}
Tres ejes sobre los que temáticamente se vertebran los principales acontecimientos: la aventura familiar, la amorosa y la político-cortesana, teniendo en cuenta que todas ellas se interfieren y que en la mayoría de los casos tienen como manifestación externa alguna demostración bélica ${ }^{6}$.
\end{abstract}

En general, estos temas propuestos sostienen la urdimbre narrativa del género caballeresco y con ellos se vincularán todos los acontecimientos, dando lugar a las más diversas secuencias y a la aparición de nuevos personajes. Por un lado, la búsqueda y reparación del linaje familiar conseguirá que el caballero demuestre su destino heroico a través de sus actos. Por otro, el amor por la doncella será el motor que lo impulse a emprender el camino, a combatir y a librar las más extrańas aventuras para conseguir honra y fama, y convertirse así en el más digno merecedor de su amor. Finalmente, la aventura cortesana hará posible que el caballero, con sus acciones, sea capaz de reestablecer el equilibrio perdido ${ }^{7}$.

La técnica utilizada en los libros de caballerías para combinar todos estos acontecimientos es el entrelazamiento y fue utilizada con anterioridad por el roman artúrico. En palabras de Cacho Blecua, es "el relato de una, dos o más historias pertenecientes a personas diferentes y ocurridas en distintos espacios, en la mayoría de las ocasiones en tiempos

6 José Manuel Cacho Blecua, "Introducción”, en Amadis de Gaula, Madrid, Cátedra, 2012, I, p. 111.

7 Conviene recordar que entendemos "aventura" como una "prueba de armas o maravillosa" mediante la cual el caballero conseguirá lograr su perfeccionamiento y el ascenso social, tal como la define María Carmen Marín Pina, Edición y estudio del ciclo español de los Palmerines (microfichas, tesis doctoral inédita), Zaragoza, Universidad de Zaragoza, 1988, p. 151. 


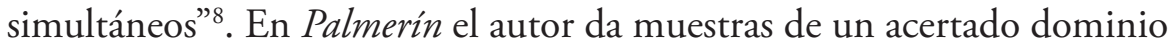
de esta técnica, mediante la cual irá intercalando varias líneas argumentales correspondientes a distintos personajes; no obstante, no será el único recurso que utilice el autor para organizar la estructura, pues combinará el entrelazamiento, propio de la poética de los libros de caballerías, con otros procedimientos narrativos que permitan intercalar los distintos episodios y personajes, dando como resultado una estructura compleja.

En su estudio del ciclo castellano de los Palmerines, Marín Pina estableció que la estructura de la primera obra del ciclo se organizaba mediante bloques o secuencias narrativas. Dichas secuencias estarían formadas "por un número variado de aventuras que poseen, a su vez, su propia estructura y encuentran en dicha secuencia el marco de su desarrollo" Efectivamente, se observa que la obra comprende una estructura general, o superestructura, que a su vez encierra una serie de estructuras menores dentro de las cuales se articularán todas las historias. Será en estas últimas en las que detendremos nuestra atención para este trabajo. Aunque nuestro propósito se centra en la aventura del héroe en su viaje por territorio musulmán, conviene explicar brevemente el cańamazo narrativo de la obra en el que se enmarca.

Como se ha indicado antes, Cacho Blecua habló de tres grandes ejes temáticos en Amadis que corresponderían a sendos tipos de aventuras del héroe. Frente a esto, en Palmerín destacan dos grandes núcleos temáticos, los concernientes a la familia y al amor:

- Núcleo A (caps. IV-XI; CV-CXV): corresponde a la esfera familiar del héroe; lo encontramos al inicio de la obra y tiene como protagonistas a Griana y Florendos. Su cierre creará una intersección con el núcleo $\mathrm{B}$, en la que se producirá la anagnórisis de Palmerín, su proclamación como emperador y el matrimonio público de los padres.

- Núcleo B (caps. XII-CIV; CXVI-CLXIV): corresponde a la errancia caballeresca del héroe y a su relación con la doncella Polinarda; ambos son los protagonistas. Este núcleo se cierra de nuevo con un matrimonio público entre Palmerín y Polinarda.

8 Juan Manuel Cacho Blecua, "El entrelazamiento en el Amadis y en las Sergas de Esplandián”, en Studia in honorem prof. M. de Riquer, Barcelona, Quaderns Crema, 1986, pp. 235-271 (p. 236).

9 M. ${ }^{a}$ Carmen Marín Pina, op. cit., p. 136. 
Además, en estos dos núcleos temáticos encontramos secuencias narrativas menores que se irán superponiendo a las principales. Marín Pina ya había detectado los dos grandes bloques narrativos que hemos indicado y había demostrado con acierto que una secuencia concluía o se desplazaba para dar paso a la siguiente ${ }^{10}$. Por nuestra parte, consideramos que el autor emplea diferentes procedimientos para enlazarlas; observamos que la correspondiente al núcleo $\mathrm{B}$ comienza sin que la del núcleo $\mathrm{A}$ haya concluido. Griana debe abandonar a su hijo recién nacido antes de que descubran que es el fruto de su amor con Florendos (A). Tras el abandono del niño por parte de Cardín, se intercala el episodio en el que Geraldo lo encuentra y comienza a criarlo junto a su mujer como si fuera hijo suyo (B). La trama correspondiente a los padres de Palmerín aún se prolongará dos capítulos más, en los que se expone cuál es la situación de Griana y Florendos en el momento en el que su hijo comienza una vida como villano. A partir de aquí, la historia se ocupará por extenso de la vida del héroe y de sus aventuras hasta que el caballero esté preparado para poder reconocer a sus padres y concluir así su hilo narrativo. El autor emplea, en un primer momento, el entrelazamiento para hilvanar ambos núcleos de forma que deja al primero (A) en un estado subyacente, esperando a que el personaje pueda concluir o alcanzar un determinado estado que le permita culminar este hilo narrativo.

El carácter inconcluso de A se recuerda en las continuas interferencias que recibe el héroe en forma de mensajes, objetos o personajes que van recordándole sus orígenes y su pertenencia a un linaje real. Cuando se están relatando las primeras aventuras de Palmerín (B), la presencia del núcleo A sigue manifestándose en tanto que la errancia caballeresca del héroe se ve influida por este núcleo; por lo tanto, estas irrupciones dan muestra de que la historia continúa latente para el personaje y, por ende, no está cerrada. Como se ha indicado, la obra comienza con la historia de amor de los padres del héroe, Florendos y Griana (A), historia que, tras el abandono del recién nacido y la separación de estos, enlaza con la historia de Palmerín (B). Sus primeros años de vida aparecen resumidos hasta el acontecimiento más importante, que provocará un cambio sustancial en la vida del personaje: el enamoramiento de Polinarda. Hasta que se produzca el encuentro con la doncella, la historia nos narrará todas las aventuras caballerescas que conduzcan al héroe hasta ella: 
1. Lucha con la leona que ataca a Estebón (cap. XIII).

2. Encuentro con el enano Urbanil (cap. XV).

3. Investidura de Palmerín como caballero por su desconocido padre Florendos (cap. XVI).

4. Aventura de la sierpe en la corte de Macedonia (cap. XVII).

5. Lucha junto al Duque de Duraço contra el duque de Ponte (cap. XXI).

6. Confusión con Laurena (cap. XXII).

7. Aventura de la espada de la arquilla (cap. XXIII).

8. Lucha contra el gigante (cap. XXV).

9. Encuentro con Adrián (cap. XXVII).

10. Lucha contra el caballero hechizado de Gante: encuentro con Polinarda (caps. XXIX-XXX).

Todas estas aventuras, personajes y objetos que ha encontrado o recibido Palmerín han tenido como último objetivo hacerle llegar hasta la princesa alemana. El amor hacia ella ha sido el principal motor en todos los capítulos. Tras su primer encuentro, el enamoramiento de ambos será rápido y la confesión de sus sentimientos solo reafirmará el amor que ambos se profesan. Una vez que es aceptado como su caballero, Palmerín se enfrentará a aventuras que demuestren el servicio hacia su señora y que lo conviertan en el más digno merecedor de su corazón. Los torneos de París, a los que el caballero acude para demostrar que la belleza de Polinarda no tiene igual, serán su primera demostración de servicio amoroso y le otorgarán la victoria frente a los mejores caballeros allí reunidos. El amor entre Polinarda y Palmerín se reafirmará cuando celebren el matrimonio secreto y este culmine con el encuentro sexual. Hasta este punto, el héroe ha conseguido el amor de la doncella y ha demostrado ser el más digno de la mano de la dama. No obstante, Palmerín desconoce su linaje, por lo cual debe concluir este punto vital de su carrera caballeresca que le permita seguir ascendiendo hasta lograr ser el mejor caballero del mundo y poder reconocer públicamente su amor con Polinarda. Antes de llegar hasta ahí, la historia va a presentar dos hilos narrativos correspondientes a los dos viajes que realizará Palmerín a tierras infieles y que tendrán una justificación narrativa en el perfeccionamiento del héroe. 


\section{El VIAJE: SENTIDO Y ESTRUCTURA}

El viaje es un tema universal presente en la tradición literaria desde la antigüedad clásica con La Odisea de Homero, y que cobrará gran importancia en la literatura áurea y, especialmente, en la novela griega o bizantina ${ }^{11}$. La aparición del viaje tiende a interpretarse como una influencia de este tipo de novela, pero recordemos que este texto es anterior a la difusión castellana del género bizantino.

Desde un punto de vista geográfico, en los libros de caballerías podemos encontrar dos tipos de viajes: el que realiza el caballero en tierra, la errancia más frecuente, comenzando la aventura al abandonar la corte y emprender el camino, y el marítimo, como en este caso, que alejará a los personajes de su destino y los llevará por tierras lejanas. Acerca del viaje marítimo, Marín Pina observa que "además de ser el medio de unión de la geografía real antes citada, del mundo oriental y occidental, es el trampolín a lo maravilloso y desconocido, a la geografía fantástica representada por las islas" ${ }^{12}$. En el género caballeresco podemos rastrear este significativo tema, gracias al cual los personajes viven y experimentan travesías marítimas que los llevan a islas encantadas o a parajes alejados y desconocidos ${ }^{13}$. En ocasiones, viajan en naves maravillosas que permiten arribar a su destino sin contratiempos. En cambio, en otras ocasiones, sufren las inclemencias del tiempo, que — como a Ulises - los aleja de su rumbo para regresar a su tierra. Este es el caso de Palmerín y sus compañeros, cuyo destino se verá desviado por una tormenta que los hará naufragar hasta territorio de dominio musulmán. El viaje y la posterior estancia en zona enemiga será, por tanto, crucial para el desarrollo de los personajes palmerinianos, aportando dinamismo y complejidad a la historia.

11 Sin duda, el tema ya había aparecido en la literatura castellana en el Libro de Apolonio o el Libro del caballero Zifar, por citar solo dos ejemplos.

12 M. ${ }^{a}$ Carmen Marín Pina, op. cit., p. 250.

13 Según Batjin, los rasgos que identifican el cronotopo de estas obras son "un mundo milagroso en el tiempo de la aventura. En cierto modo este cronotopo está delimitado de manera muy consecuente. Les son propias no ya las rarezas y las curiosidades, sino lo milagroso; cada objeto — arma, vestimenta, fuente, puente, etc. - tiene en él ciertos poderes mágicos o, simplemente, está encantado. En ese mundo existe también mucha simbología; pero ésta no constituye un simple jeroglífico, sino que se aproxima a la simbología fantástica oriental" (Mijail Batjin, Teoría y estética de la novela, Madrid, Taurus, 1989, p. 306). 
Palmerín, Trineo y Tolomé abandonan Inglaterra llevándose a Agrio$\mathrm{la}^{14}$. En esta huida, el autor quiere resaltar el destino fatal que les aguarda a los personajes, por lo que utiliza esta fórmula anticipatoria para preparar al receptor sobre los nuevos acontecimientos: "Mas poco les turó aquel plazer, que la fortuna, que es enemiga de los bienandantes, ordenó que aquel grande plazer fuese tornado en dolorosos llantos e gemidos, como vos contaremos" 15 . Una tormenta hará que naveguen sin rumbo conocido durante veinte días hasta arribar a tierra; de este viaje tan solo conocemos la duración, pues no se aportan más detalles del mismo. Desafortunadamente, los personajes llegan al señorío del soldán de Babilonia, territorio hostil para un cristiano. A partir de este momento, se separan, razón por la que el relato se divide para centrarse en cada uno de ellos de forma separada.

Palmerín es el primero que se aleja de sus compañeros porque sale a cazar y nunca volverá al barco. Se trata de un territorio infiel, por lo que, al ser descubierto, se ve obligado a quedarse allí. A esa tierra llegan varias naves turcas lideradas por Olimael, caudillo del Gran Turco, que también han sufrido las inclemencias del tiempo y navegaban a la deriva. Al ver el barco cristiano, lo asaltan y secuestran a Agriola para llevársela al Gran Turco, junto con Tolomé. Trineo, en cambio, será entregado como cautivo a un primo de Olimael ${ }^{16}$. La trama vivida de estos personajes y sus aventuras se desarrollarán en cuatro lugares diferentes:

\section{Palmerín: señorío del Soldán de Babilonia \\ 2. Trineo: isla de Malfado \\ 3. Agriola: tierras del Gran Turco \\ 4. Tolomé: señorío del Soldán de Babilonia}

14 Los caballeros han viajado a Inglaterra con la excusa de ayudar al rey en la guerra que tiene contra Escocia. No habría nada de extraño en esto si no fuera porque Alemania es enemiga de la corte inglesa. El motivo no es otro que el amor prohibido de Trineo por Agriola, hija del rey. Una vez que Trineo y Palmerín conocen los sentimientos de la princesa hacia el heredero alemán, la coaccionarán para marcharse cuanto antes de allí pues, recordemos, estaban en la corte enemiga.

15 Palmerin de Olivia, ed. Giuseppe di Stefano, Alcalá de Henares, Centro de Estudios Cervantinos, 2004, p. 157.

16 Sobre el cautiverio, vid. José Julio Martín Romero, "La influencia de los libros de caballerías en las obras cervantinas sobre el cautiverio", Nueva Revista de Filología Española, LXIII, 2 (2015), pp. 371-397. 
El barco en el que viaja Trineo con los turcos naufraga hasta llegar a la isla de Malfado en el señorío de Persia ${ }^{17}$. Esta isla está hechizada, por eso cuando Trineo y el resto de la tripulación entran en ella se transforman en animales debido a un encantamiento: "luego fueron encantados todos de tal manera que no sabían de sí parte"18. Por su parte, Agriola es entregada al Gran Turco como compensación por las pérdidas que han sufrido las huestes de Olimael. La doncella será forzada a casarse en contra de su voluntad; pero, para fortuna de Agriola, por la acción de un anillo mágico que protege su virginidad, el Gran Turco no podrá consumar el matrimonio. Por último, Tolomé se convierte en cautivo de un señor en Babilonia. El hecho de que los personajes se separen por diversos motivos como los raptos o la caza viene a acentuar el valor negativo con el que se inicia esta trama narrativa en la que cada uno vivirá en un ambiente desfavorable y peligroso: "E ansí como vos dezimos acaesció a Trineo e a los que lo llevaban cautivo. E dexarlos emos fasta su tiempo e dezirvos emos lo que avino Agriola después que Trineo fue apartado d'ella" ${ }^{19}$. El autor

17 En la obra no encontramos descripciones de las islas. Tan solo algunos personajes manifiestan que aquella tierra les parecía un lugar deleitoso para arribar después de varios días a la deriva. A pesar de que la isla de Malfado es un lugar mágico, tampoco encontramos detalle alguno sobre su orografía maravillosa. La isla, como tópico espacial ha sido ampliamente estudiada por Axayácatl Campos García Rojas, "La Ínsula del Ploto en Tristán de Leonis y la construcción de un legado: el modelo ejemplar de los Reyes Católicos", en Fechos antiguos que los cavalleros en armas passaron: estudios sobre la ficción caballeresca, coord. Julián Acebrón Ruiz, Lleida, Universidad de Lleida, 2001, pp. 75-96; Axayácatl Campos García Rojas, "Centros geográficos y movimiento del héroe: de la Ínsola Firme a la Peña Pobre en el Amadís de Gaula", Voz y Letra: revista de literatura, 11, 2 (2000), pp. 3-20; Juan Carlos Pantoja Rivero, "Las ínsulas y sus habitantes en el Amadis de Gaula: un acercamiento a la geografía mítica de los libros de caballerías", Per Abbat: Boletín Filológico de actuación Académica y Didáctica, 7 (2008), pp. 127-141; José Manuel Lucía Megías, "Sobre torres levantadas, palacios destruidos, ínsulas encantadas y doncellas seducidas: de los gigantes de los libros de caballerías al Quijote", en Fantasía y literatura en la Edad Media y los Siglos de Oro, coords. Nicasio Salvador Miguel, Santiago López-Ríos Moreno y Esther Borrego Gutiérrez, Madrid/Frankfurt Iberoamericana/Vervuert, 2004, pp. 235-258.

18 Palmerín de Olivia, op. cit., p. 159. La isla de Malfado recuerda a la isla de Circe en La Odisea. Al igual que la hechicera homérica, la maga de esta isla también transfigura en animales a quienes llegaban a su isla. Trineo quedará allí bajo el influjo del poder maligno de Malfado esperando a que alguien pueda romper el hechizo.

19 Ibidem, p. 160. 
ha dispersado a cada personaje en un hilo narrativo diferente - mediante el entrelazamiento- colocándolos en una situación difícil.

Según Baquero Escudero, este esquema argumental que hemos indicado es propio de la novela griega y responde a una sucesión de determinados hechos que se podrían ordenar de la siguiente forma: encuentro, separación, búsqueda y reencuentro ${ }^{20}$. El autor ha situado a cada uno de los personajes en un punto geográfico distante dejando tramas abiertas para que Palmerín, como protagonista absoluto de esta obra, consiga reunir de nuevo a sus compañeros superando pruebas y obstáculos.

La estructura compuesta de tramas y subtramas que quedan abiertas y que se entrelazan crea un efecto de intriga que se va intensificando a medida que avanza la acción. Esta disposición de las historias consigue crear expectación en el receptor y así mantenerlo atento hasta la resolución de todos y cada uno de los conflictos. No obstante, se demostrará que no es solo una estructuración narrativa de las historias, sino que presentará otra función vinculada a la configuración del héroe y de otros protagonistas.

Como se ha visto, la dispersión de tramas comienza con la separación de Palmerín; a continuación, se narrarán las separaciones del resto de personajes. Mediante el entrelazamiento, la línea argumental retomará la historia de Palmerín. Recordemos que Palmerín había salido a cazar solo y descubre que se encuentra en tierras infieles. Para sobrevivir, se verá obligado a fingir que no es cristiano y tendrá que hallar el modo de regresar a su tierra sin ser descubierto. Podría considerarse que el deseo de reencontrarse con su amada Polinarda se convierte así en la causa generadora de todo este episodio; es decir, aquello que empuja al héroe a la acción y que dominará internamente todos sus esfuerzos. En tanto que Palmerín debe encontrar la manera de abandonar las tierras del señorío del Soldán de Persia sin que sospechen de su fe cristiana, muchas de las aventuras pondrán en riesgo su integridad no solo física sino también sentimental e, incluso, religiosa ${ }^{21}$.

Su estancia en la corte del soldán no solo demostrará la astucia y el valor del caballero para sortear una serie de infortunios que pondrán su vida

20 Ana L. Baquero Escudero, "La novela griega: proyección de un género en la narrativa espańola”, RILCE, VI, 1 (1990), pp. 19-45.

21 Estos tres aspectos coinciden con los ya observados por Lucila Lobato Osorio, "Los tres ejes de comportamiento del caballero literario medieval: hacia un modelo genérico", Tirant, 11 (2008), pp. 67-88. 
en serio peligro. Palmerín verá tambalearse su integridad moral y amorosa ante el acoso sentimental al que será sometido por parte de las doncellas con las que se encuentra. Ante esto, el caballero tendrá que ingeniárselas para esquivar sus requerimientos amorosos.

Podemos resumir los bloques narrativos de las pruebas a las que Palmerín se enfrenta así:

1. Lealtad amorosa hacia su señora Polinarda, al mantenerse firme ante el acoso de las doncellas musulmanas. Prueba mágico-maravillosa de la corona de Manarix para confirmar la lealtad hacia su amada.

2. Defensa de Alchidiana al ser acusada injustamente por la muerte de Ardemia. Su bondad como caballero se demostrará al defender a la doncella sin importarle la diferencia de credo. Estratega militar: sus dotes guerreras le brindan la confianza del soldán, que lo nombra caudillo para liderar sus huestes contra Constantinopla.

3. Ocultación de su fe cristiana para sobrevivir en tierras infieles. A pesar de la diferencia de credo, el caballero podrá tener una relación amistosa con personajes musulmanes como el infante Olorique.

Cada aventura supone una demostración de las habilidades del caballero, ya sean guerreras, religiosas, cortesanas o amorosas ${ }^{22}$. Quizá lo que tenga mayor importancia de todo lo que le ocurre al personaje en estos episodios será el descubrimiento de alto linaje $\mathrm{e}^{23}$. El tiempo que ha pasa-

22 Cabe destacar que no siempre lo conseguirá plenamente, como ocurre en un episodio en el que la Reina de Tarsis, atraída por la belleza del caballero, después de haberle dado un bebedizo que provoca que pierda toda consciencia, abusará de él sexualmente. Parece recordar el episodio artúrico de la procreación de Galaz, si bien con matices diferentes, aunque Lanzarote tras el bebedizo tenía alguna consciencia de que estaba yaciendo con Ginebra. A este respecto, vid. Carlos Alvar, "Galaz", en El rey Arturo y su mundo. Diccionario de literatura artúrica, Madrid, Alianza Editorial, 1991, pp. 179-181. De este encuentro sexual nacerá Polendos, pero no será considerado como una deslealtad hacia Polinarda, pues el caballero no era dueńo de su voluntad y, por lo tanto, no fue un hecho consciente.

23 La confirmación de su alto linaje se produce en la obra en diferentes momentos y por boca de varios personajes. En una de las aventuras que vivirá el héroe, se requerirá su ayuda para salvar a la hija de una dueña que ha sido hecha prisionera. Esta dueña le 
do Palmerín en tierras del soldán ha sido propicio para que el caballero demuestre sus extraordinarias cualidades. Sin embargo, aún necesita conocer a sus padres y confirmar así su origen real para poder hacer público su amor y celebrar las bodas con Polinarda.

Una vez concluida esta etapa en tierras del soldán de Babilonia, Palmerín vuelve a la corte donde le espera su señora. El proceder caballeresco que empuja al héroe a buscar aventuras lo conducirá a una en la que defenderá a su padre, Florendos, sin saber su identidad. Esto le permitirá conocer así sus orígenes reales y ser reconocido por sus padres. De esta forma, el caballero reparará el daño que habían sufrido Florendos y Griana, reestablecerá el equilibrio en su relación amorosa y podrán celebrar su matrimonio público. Con todo esto, el núcleo A (la relación de sus progenitores y la recuperación del linaje por parte del héroe) quedará cerrado cuando Palmerín sea reconocido como emperador de Constantinopla (cap. CXII). A partir de este momento, la historia se enlaza con el núcleo $\mathrm{B}$, porque queda pendiente el matrimonio público entre Palmerín y Polinarda ${ }^{24}$.

Como vemos, la disposición de las tramas en este primer viaje genera cierto dinamismo en la estructura general. Entre la separación y el reencuentro (y posterior desenlace de la trama), se incrementa la peligrosidad y el riesgo en cada episodio. Cabe destacar la tensión que se origina al no cerrar la trama debido a que el personaje necesita cumplir otra misión que le permita acabar la aventura en la que se inserta ${ }^{25}$.

mostrará unas armas que su hermana había dejado para él anteriormente. Las armas estaban cubiertas por un paño blanco en el que estaba escrito en griego que él era "hijo del rey más leal que en Grecia fallarse pudo", Palmerín de Olivia, op. cit., p. 136. Posteriormente, el caballero se ofrecerá a luchar por la doncella Alchidiana, pero será rechazado por otro caballero al no ser hijo de rey. Ante la imposibilidad de conocer eso, tanto por el soldán como por el propio Palmerín, será un doncel enviado por la reina de Tarsis quien despeje las dudas. Le entregará un yelmo y confirmará que Palmerín procede de un linaje superior al de ninguno de los allí presentes (Ibidem, p. 179). Será precisamente esta dueña quien, en un encuentro posterior con el caballero, le confirmará las palabras que de él le había dicho un sabio, anticipándole el hecho que le permitiría reconocer a sus padres (Ibidem, p. 194).

24 El final del núcleo A tiene una continuación en el núcleo B al enviar Palmerín una embajada a Alemania para pedir la mano de Polinarda.

25 Sobre la intriga en la narración, vid. Lucila Lobato Osorio, "La función de la aven- 
El segundo viaje presentará una estructura totalmente diferente. Para entender su trama debemos volver al capítulo XLIX, en el que se narra la despedida de Trineo y Polinarda antes de que este marchara hacia Inglaterra: "Ruégovos que no vos caséys, aunque el Emperador vos lo mande, fasta que yo venga" 26 . Esta promesa de Polinarda a su hermano enlaza con la petición que le hará posteriormente en el capítulo XCVIII a Palmerín: "Pues que ansí es, que perdiste de tal manera a Trineo, también él estará en lugar adonde no podrá venir. Conviene que lo vays a buscar, por amor del Emperador" ${ }^{27}$. Se trata, por tanto, de un nuevo impedimento para que se cierre el relato de la boda pública de Palmerín y Polinarda. De esta manera, la motivación del segundo viaje es encontrar a Trineo y al resto de compañeros. También aquí el viaje lo llevará a tierras musulmanas, en las que el héroe revelará nuevas facetas de su personalidad, una personalidad que se irá construyendo paulatinamente mediante sus propias vivencias. La subtrama de este viaje se cerrará con el regreso de todos ellos a Alemania, que permitirá, a su vez, que, con el matrimonio público, concluya el núcleo $\mathrm{B}$, correspondiente a los amores entre Palmerín y Polinarda.

También en esta ocasión, el héroe emprende el viaje, sin rumbo determinado, acompañado esta vez por el infante Olorique y sus caballeros. No tardarán en encontrarse unas naves musulmanas capitaneadas de nuevo por Olimael, que los tomará como cautivos ${ }^{28}$. De esta forma, bajo el mando del caudillo turco, los personajes irán saqueando y arrasando aquellas ciudades cristianas que encuentren a su paso, como es el caso del saqueo del ducado de Duraço, cuyo señor muere a manos de las huestes musulmanas ${ }^{29}$. El reencuentro de Palmerín con Laurena, hija del duque de

tura novelesca en la articulación del género caballeresco breve", en Palmerín y sus libros: 500 años, eds. Aurelio González, Axayácatl Campos García Rojas, Karla Xiomara Luna Mariscal y Carlos Rubio Pacho, México, D. F, El Colegio de México, 2011, pp. 475-490 (p. 478).

26 Palmerín de Olivia, op. cit., p. 110.

27 Ibidem, p. 204.

28 Una estrategia perfectamente estudiada por José Julio Martín Romero, op. cit., p. 439.

29 Como se recordará, en Duraço Palmerín había conocido a Laurena, hija del duque, a quien se había ofrecido como su caballero pensando que era la doncella que aparecía en sus sueños. Tras descubrir su error, partirá de la corte dejando a la doncella sin mayores explicaciones. La reaparición de este personaje en la historia podría deberse a un intento por parte del autor por concluir de forma más digna la trama de Laurena y resarcirla, de alguna manera, del desplante del caballero. 
Duraço, permitirá que la doncella no corra la misma suerte que su progenitor, ya que el caballero decide llevarla consigo ${ }^{30}$. Tras todas estas batallas, Palmerín, Laurena y Olorique llegan al señorío del Gran Turco; allí se reencuentran con Agriola. Finalmente, los personajes consiguen escapar tras matar al Gran Turco, liberando así a Agriola. En su travesía de regreso encontrarán otras naves infieles en las que viaja Estebón, el mercader, y sus hijos $^{31}$. En el relato se produce una circunstancia que le permite al autor llevar a sus personajes a un punto determinado: una tormenta marina. Efectivamente, esto hace que naufraguen y lleguen a la isla de Malfado (donde estaba, recordemos, Trineo); allí también todos ellos, a excepción de Palmerín, serán convertidos en animales ${ }^{32}$. Se crea así un obstáculo que se agrava cuando Palmerín, preso de la ira, mata a la señora de la isla antes de conseguir que esta desencantara a sus compañeros. A partir de aquí, la secuencia se complica en una concatenación de aventuras cuyas resoluciones implican nuevas tramas; así pues, los hilos narrativos principales contienen, a su vez, otros hilos menores dando lugar a una estructura subordinada. Como se ha indicado, se originan una serie de conflictos encadenados: se produce un obstáculo, en cuya resolución se introduce a su vez otro obstáculo; esto es, al héroe se le plantea una situación o aventura que debe concluir, pero, para culminarla, antes tiene que superar otra prueba que le capacite de alguna manera para finalizar la anterior.

En primer lugar, Palmerín necesita encontrar la manera de romper el hechizo para que sus compañeros recuperen su forma humana. Este motivo será el que origine las siguientes historias y aventuras. El caballero, en

30 En uno de estos saqueos, los personajes llegan al reino de Tesalia, donde matan al rey. La trama, que se inicia con la muerte de este personaje, concluirá en Primaleón, la segunda obra del ciclo. La hija del rey, Francelina, será encerrada en una torre mediante encantamientos para proteger así su vida de sus enemigos. Se trata de un tópico caballeresco en el que la doncella deberá ser rescatada por el mejor caballero que logre finalmente vencer todas las pruebas mágico-maravillosas.

31 Este personaje será fundamental en la biografía del héroe, pues será el primero que ayude a Palmerín comprándole un caballo y dotándolo de todo lo necesario para empezar su andadura antes de ser armado caballero.

32 Los encantamientos de la isla de Malfado no tienen efecto en Palmerín, ya que una de las tres hadas que encontró el caballero en la montańa Artifaria en la aventura de la sierpe le otorgó el don de no ser hechizado de ninguna manera. Así, Palmerín, a diferencia de sus amigos, no ha sido transformado en animal. 
su búsqueda de un remedio para revertir el encantamiento de Malfado, se encuentra con un personaje que le orienta en su camino hacia un determinado destino: Diardo, hijo del sabio Adrián, también está atrapado en la isla; será este quien lo dirija hacia la villa Elaýn, que gobierna la infanta Zérfira, con la esperanza de que esta pueda ofrecerle ayuda ${ }^{33}$.

En la villa Elaýn conoce a Zérfira, que le indica que quien puede ayudarle es Muça Belín. Ella también necesita encontrarse con él porque tiene un problema de salud, pero no le es posible porque mantiene un enfrentamiento con su hermano. Palmerín conoce su historia y decide ayudar a Zérfira en ese asunto ${ }^{34}$. Como vemos, el héroe ha conocido a otro personaje que no puede ayudarle directamente porque existe un impedimento, pero le da información sobre un tercero que podría solventar este asunto. A partir de aquí, la historia se proyecta hacia el futuro en una estructura compleja de tramas subordinadas. Palmerín mata al hermano de la infanta y, finalizado así este enfrentamiento, Zérfira podrá acompañar a Palmerín para encontrarse con Muça.

Los personajes deberán ir hasta Rumata, reino del rey Abimar, donde se encuentra el sabio. En este punto se abre una nueva trama que consiste en el enfrentamiento entre el rey Abimar y el soldán de Persia. Este rey, en guerra contra el soldán de Persia por consejo del sabio, necesita la ayuda de Palmerín y Trineo para poder derrotarlo. Muça Belín pondrá a prueba a Palmerín para demostrar las virtudes del caballero ante el rey. Pero antes de prestar su ayuda, deberán resolver el problema de Zérfira.

La subordinación no es solo una disposición narrativa a la hora de desarrollar la historia. Este esquema lo encontramos también en la descripción del espacio. En la aventura del Castillo de los diez padrones, a la que se tiene que enfrentar Palmerín, debe encontrar una flor maravillosa que podría curar la enfermedad de la infanta. La descripción del castillo

33 Parece ser común el encuentro del héroe con personajes que ya había conocido anteriormente y que de alguna manera vinculan los hechos presentes con los pasados, proyectándolos hacia el futuro. Así, Diardo, por quien luchó tiempo atrás, será quien le indique hacia dónde debe dirigirse Palmerín para poder encontrar el remedio que torne a sus amigos a su forma natural.

34 En este viaje Palmerín es acompañado de Trineo, que continúa transformado en perro a causa del encantamiento de la isla de Malfado, por lo que el caballero no puede reconocerlo. 
responde a una estructura de mayor a menor en la que sucesivamente un espacio grande alberga otro más pequeño. La flor que necesita el caballero está en un árbol que está en una huerta. Además, en ese árbol se cría un ave que solo come de sus flores y a quien Palmerín debe también atrapar. Esto va aportando mayor complejidad al relato al mismo tiempo que genera intriga, sensación de dificultad para poder superar las pruebas y, sobre todo, dinamismo. Una vez que Palmerín ha superado el enfrentamiento con los diez padrones, para poder acceder al castillo el caballero llega primero a un corral en el que encuentra una sepultura, y ahí una llave que señala la dirección que debe tomar. En todo momento, Palmerín es acompañado por Trineo (que sigue transformado en animal, en concreto en perro). Una vez que ambos entran en el palacio, se rompe el hechizo, una resolución inesperada por la que el personaje recupera su forma humana. En el palacio encuentran diversos objetos, así como una doncella misteriosa que los acompañará hasta la huerta donde se halla el ave. En el momento en que Palmerín lo atrapa, este otro hechizo también se rompe. Al salir de la huerta maravillosa, esta se cierra concluyendo así esta aventura. Zérfira sanará al oler las flores y, con ello, la trama de esta concluye.

Una vez finalizada esta trama, queda pendiente ayudar al rey en la guerra con el soldán de Persia. La batalla no se resolverá finalmente con la muerte del soldán, sino que Palmerín lo captura para forzar la rendición de sus huestes y darle la victoria al rey. Finalizada esta prueba a la que fueron sometidos los caballeros por Muça, parecería que van a recibir la ayuda para poder desencantar a sus amigos del hechizo de Malfado. No obstante, una nueva secuencia se abre: la de Aurencida y Liçadra, hermanas del soldán, quienes intentarán seducir a los caballeros cristianos para que se conviertan al islam y permanezcan junto a él en la corte turca. Esto alejará a los personajes de su propósito durante más tiempo ${ }^{35}$. Así, este nuevo paréntesis narrativo consiste en una prueba de fidelidad amorosa y religiosa en la que se refuerza la personalidad de ambos caballeros, y concluye con un desenlace trágico para las doncellas (Liçadra acabará suicidándose con la espada del soldán y Aurencida, aunque quedó embarazada

35 Sobre esta cuestión, vid. M. a del Pilar Casado Gutiérrez, “¡Ay señor, cómo nos valiera más la muerte que conocer a estos cavalleros cristianos!': las doncellas moras y el amor en Palmerín de Olivia", en Historias fingidas (en prensa). 
de Trineo, permaneció encerrada en su cámara durante diez años). Terminada también esta prueba, Muça les indicará cómo poder desencantar Malfado. Así se cierra la trama de las aventuras en las tierras del soldán.

Esto permite que continúen los sucesos de la isla de Malfado, donde los personajes tendrán que probarse en la aventura de la torre, que permitirá romper la maldición de la isla. Palmerín culmina esa aventura y logra deshacer para siempre el encantamiento de ese lugar. Rota la maldición, todos sus amigos, junto con los demás personajes allí atrapados, recuperan su forma humana y podrán al fin emprender el camino de regreso. El relato de la reunión de personajes tiene un episodio más durante la travesía marítima de vuelta, cuando encuentran a Tolomé, que había sido capturado por las huestes de Olimael; de esta forma el autor consigue reagrupar a todos los personajes para el regreso a Alemania y dar por concluida esta gran trama relativa a los viajes. Con el rescate del hermano de Polinarda, Palmerín ha podido concluir con éxito su último servicio amoroso, requisito indispensable para poder celebrar sus bodas públicas y, con ellas, cerrar el núcleo $\mathrm{B}^{36}$. Toda esta compleja estructura consigue crear intriga dejando el cierre de la trama amorosa de Palmerín y Polinarda para el final ${ }^{37}$.

\section{Conclusión}

En las tramas de los dos viajes que realiza el caballero a tierras infieles observamos que, aunque el autor tiende a la composición de estructuras parejas, el armazón narrativo correspondiente a cada viaje se resolverá de forma muy diferente. El primero sirve para plantear las tramas y la situa-

36 Conviene recordar una trama que aparece intermitentemente en el último viaje del caballero. Cuando Palmerín llega a tierras del soldán de Babilonia, conocimos el amor no correspondido de Alchidiana por él. A pesar de haberse marchado de las tierras del soldán y de no haberle sido del todo sincero, la doncella no ha podido olvidar sus sentimientos por el héroe. La trama, por tanto, no está cerrada y en diversas ocasiones encontraremos esas interferencias de la historia de Alchidiana en su búsqueda de noticias sobre el caballero. Este recurso del entrelazamiento, que hemos visto que se utiliza para unir diferentes tramas narrativas, le sirve al autor, en este caso, para mantener la trama de la doncella presente para el receptor y evitar así que una historia que ocurrió tan atrás en la obra pueda olvidarse.

37 Como indica Lucila Lobato Osorio, op. cit., p. 480. 
ción de cada personaje, centrándose en el héroe y su estancia en tierras infieles. El segundo servirá de cierre de todos los hilos abiertos, resolviéndose con mayor complejidad tanto en lo que se refiere a la estructura como a la historia de los protagonistas. La estancia de estos personajes durante los numerosos capítulos en los que se desarrollan las tramas mencionadas tendrá una relevancia capital, pues revelará sus respectivas personalidades, destacando sobremanera las cualidades de Palmerín si las comparamos con las de sus compañeros ${ }^{38}$. La experiencia del viaje será un recorrido de experimentación y búsqueda de la propia identidad, pues, en la pérdida, cada personaje librará su propia guerra ante la adversidad. Podemos decir, por tanto, que ambos viajes, en la trayectoria vital de Palmerín, sirven, en primer lugar, como reconocimiento y, a continuación, como perfeccionamiento de sus cualidades.

Estos episodios preludian las aventuras de encuentros y separaciones de la novela bizantina, y bien pudieron influir en algunas obras castellanas del este género. Como se ha visto, la habilidad narrativa del autor de Palmerín es notable, pues fue capaz de tejer una compleja red de relatos mediante diferentes procedimientos de engarce narrativo. Para esto, el autor empleó el entrelazamiento como signo distintivo de la poética del género, pero, además, creó una estructura jerárquica en la que tramas mayores encierran otras menores, dejando suspendidas las primeras y logrando provocar una sensación de intriga y expectación en el receptor de la historia ${ }^{39}$. Por tanto, esta obra no está compuesta por una serie de episodios acumulados en sarta. La estructura y disposición de los hilos narrativos deja de ser caprichosa cuando tienen una justificación tanto para la historia como para los personajes y, si se eliminara del relato, este dejaría de tener sentido. Palmerín de Olivia es una superestructura narrativa que contiene a su vez una gran variedad de tramas y subtramas articuladas en

38 Como afirma Lucila Lobato Osorio, op. cit., p. 476, "cada aventura contribuye al perfeccionamiento del protagonista para convertirlo en el mejor caballero del mundo, en el amante más leal y apasionado o en el guerrero más devoto".

39 Esta habilidad narrativa que observamos en el autor palmeriniano a la hora de configurar la estructura de la obra se encontrará en Silva. Para esta cuestión, vid. Juan Pablo Mauricio García Álvarez, "Alternativas narrativas para enlazar historias en la Primera parte del Florisel de Niquea (caps. VI-XXI)", en Literatura y ficción: "estorias", aventura y poesía en la Edad Media II, ed. Marta Haro Cortés, Valencia, Publicacions de la Universitat de València, 2015, pp. 489-502. 
dos grandes temas o núcleos: la esfera familiar del héroe y el amor, cohesionadas en una arquitectura sabiamente organizada.

El autor del Palmerín ofrece nuevos paradigmas narrativos en la conformación de la obra que combina el entrelazamiento, propio del roman artúrico — que ya aparecía en las obras de Montalvo-, con otros procedimientos que complican la trama y aportan tensión y suspense a las historias. 